\title{
Distribution and Accumulation of Heavy Metals in Surface Sediment of Lake Junín National Reserve, Peru
}

\author{
María Custodio*, Fisher Huaraca, Ciro Espinoza, Walter Cuadrado \\ Universidad Nacional del Centro del Perú, Huancayo, Perú \\ Email: *mcustodio@uncp.edu.pe
}

How to cite this paper: Custodio, M., Huaraca, F., Espinoza, C. and Cuadrado, W. (2019) Distribution and Accumulation of Heavy Metals in Surface Sediment of Lake Junín National Reserve, Peru. Open Journal of Marine Science, 9, 33-48. https://doi.org/10.4236/ojms.2019.91003

Received: January 2, 2019

Accepted: January 22, 2019

Published: January 25, 2019

Copyright () 2019 by author(s) and Scientific Research Publishing Inc. This work is licensed under the Creative Commons Attribution International License (CC BY 4.0).

http://creativecommons.org/licenses/by/4.0/

(c) (i) Open Access

\begin{abstract}
The distribution and accumulation of heavy metals in the surface sediment of Lake Junin National Reserve was evaluated using the pollution factor $(C F)$, pollution load index $(P L I)$ and geoaccumulation index $\left(I_{\text {geo }}\right)$, during 2018. Surface sediment samples were collected from 10 sampling sites, with three repetitions, during the rainy and dry seasons. The heavy metals determined were $\mathrm{Fe}, \mathrm{Cu}, \mathrm{Cr}, \mathrm{Cd}, \mathrm{Pb}$ and $\mathrm{Zn}$; As, was also determined. The results revealed the descending order of $\mathrm{Fe}>\mathrm{Cu}>\mathrm{Zn}>\mathrm{As}>\mathrm{Pb}>\mathrm{Cd}>\mathrm{Cr}$ concentrations recorded in the three sampling sectors. The values of the $C F$ obtained for the metals qualified as low $C F$, in times of rain and low water. The $C F$ values of $\mathrm{Cd}$ were qualified as moderate contamination factors at all sampling sites, except at LJ1 where it qualified as $C F$ considerable. The $P L I$ for Lake Junin ranged from 0.0721 to 0.3260 . The $I_{\text {geo }}$ obtained indicated that the sampling sites are not contaminated by the heavy metals under study. Therefore, the mean values for heavy metals and As did not exceed the reference values and sediment quality guidelines. In general terms, $C F, P L I$ and $I_{g e o}$ indicate that there is no appreciable contamination by these metals in Lake Junin; except for $\mathrm{Cd}$.
\end{abstract}

\section{Keywords}

Lake Sediment, Sediment Quality, Contamination Factor, Load Index, Geoaccumulation Index

\section{Introduction}

Pollution of the aquatic environment by heavy metals is one of the main problems worldwide, as it affects not only the physical environment but also the functioning of ecosystems. Once released into the environment, heavy metals 
circulate between biotic and abiotic cycles, accumulate in different compartments of the food chain and can reach toxic concentrations for animals, plants, microorganisms and even humans [1]. The presence of heavy metals in the environment is due to natural processes (erosion, atmospheric deposition and geological meteorization) and anthropogenic processes (industrial processes, domestic waste, agricultural activities and vehicle emissions) [2].

At present, heavy metals are of great importance as indicators of the ecological quality of any aquatic ecosystem due to their toxicity and bioaccumulative behavior. Water pollution by heavy metals is a major environmental problem in modern society. Pollutants enter the aquatic environment through the discharge of wastewater from industrial, urban, and agricultural runoff, and are released, and are trapped in suspended colloidal sediments before sinking into bottom sediments [3]. Subsequently, they can accumulate in aquatic biota, and become organic complexes and biomagnify in the food chain [4]. In addition, lake sediments are the secondary source of pollution that restricts water quality; heavy metals cannot be removed by the self-purifying capacity of the water [5].

Sediments play a fundamental role in the cycling of heavy metals in the aquatic environment; they are involved in the transport of many nutrients and pollutants. They also mediate their uptake, storage, release and transfer between environmental compartments. The liberation of heavy metals from the sediment to the water column will depend on the chemical fractionation of the metals, the $\mathrm{pH}$ of the sediment, and the physical and chemical properties of the water [3]. Determination of the spatial distribution of heavy metals in the sediment is essential to provide information on pollutant sources and to prioritize mitigation strategies. To date, various methods have been developed to determine the degree of pollution, safeguard the health status of the aquatic system and facilitate ecological risk management. The most commonly used indices in sediment pollution studies are the geoaccumulation index (Aegean), the enrichment factor $(\mathrm{EF})$, the pollution factor and the pollution load index (PLI) [6] [7].

In Peru, high Andean wetlands remain the least studied and represent one of the most threatened ecosystems. The decline in water quality that these ecosystems have been experiencing due to their inadequate management, despite the fact that they play a fundamental role in human well-being and the maintenance of ecological balance [8] requires a more integrated knowledge of the various processes that occur. Lake Junín is located in the Junín National Reserve, in the central Andes of Peru at 4090 meters above sea level. In 1997 it was recognized by the Ramsar Convention as a wetland of international importance, as an important habitat for some 20,000 waterbirds, including endangered endemic species such as the Junín grebe (Podiceps taczanowskii), the black redfish (Laterallustuerosii) [9] and the endangered Junín giant frog (Batrachophrynus macrostomus) and present native flora of the puna, as well as for the impressive scenic beauty it shows.

In this context and considering that Lake Junín plays a transcendental role in the origin of the Mantaro River (main tributary of the Amazon basin), which 
supplies water for the development of agricultural activities, fish farming and electricity generation [10], the need arises to use tools that allow monitoring the quality of these ecosystems in order to achieve a sustainable management of wetlands. The objective of this study was to evaluate the distribution and accumulation of heavy metals in the surface sediment of Lake Junin using the contamination factor, contamination load index and geoaccumulation index.

\section{Materials and Methods}

\subsection{Study Area}

Lake Junin is located in the Junín National Reserve, in the central Andes of Peru at 4090 meters above sea level. It is the highest lake and the second largest in Peru after Lake Titicaca, with an extension of 34 kilometers long by 16 wide and a depth of 12 meters. The lake is fed mainly by the San Juan River, located at the northwest end of the National Reserve whose average annual discharge is $286,030,000 \mathrm{~m}^{3}$, with maximums of up to $114.7 \mathrm{~m}^{3} / \mathrm{s}$ and minimums of up to $1.01 \mathrm{~m}^{3} / \mathrm{s}$. The lake is fed by the San Juan River, located at the northwest end of the National Reserve whose average annual discharge is $286,030,000 \mathrm{~m}^{3}$, with maximums of up to $114.7 \mathrm{~m}^{3} / \mathrm{s}$ and minimums of up to $1.01 \mathrm{~m}^{3} / \mathrm{s}$. The lake drains on the northwest side through the Upamayo dam, which came into operation in 1936, giving rise to the Mantaro River, which is one of the main Andean tributaries of the Amazon basin [9]. Lake Junin forms an important hydrographic system of high productivity and biological diversity (Figure 1). However, over the years it has experienced strong anthropogenic pressure, due to excessive extraction of resources, contamination of water by mining tailings and municipal wastewater, and generation of electricity [11].

\subsection{Collection of Surface Sediment}

The collection of the surface sediment (top $10 \mathrm{~cm}$ ) was carried out in the 10 interior sites of the lake by means of a Hydro-Bios Ekman-Birge dredge. Three sediment samples were collected at each sampling site. The sediment samples were digested according to USEPA 3051 [12] with some modifications. In summary, 1.00 gram of dry sample was transferred to a $150 \mathrm{ml}$ beaker, $2.5 \mathrm{ml}$ of nitric acid $\left(\mathrm{HNO}_{3}\right)$ and $10 \mathrm{ml}$ of hydrochloric acid $(\mathrm{HCl})$ were added; the beaker was covered with a clock moon and led to digestion by the microwave-assisted method. The established digestion program was: 17 minutes at $120^{\circ} \mathrm{C}, 15$ minutes at $210^{\circ} \mathrm{C}$ and 30 minutes at $210^{\circ} \mathrm{C}$. After cooling the digestion product was transferred to a $100 \mathrm{ml}$ pan and gauged with ultrapure water. The sample was stored at $4^{\circ} \mathrm{C}$ and filtered before analysis.

The determination of heavy metals and arsenic was performed by the method of atomic absorption spectrophotometry by flame (air-acetylene) using the Perkin Elmer Analyst AA-6800 atomic absorption spectrometer, Shimadzu brand. Previously, the standard solutions were prepared and read in increasing order of concentration with which the calibration curve was elaborated and then the reading of the respective samples was made. 


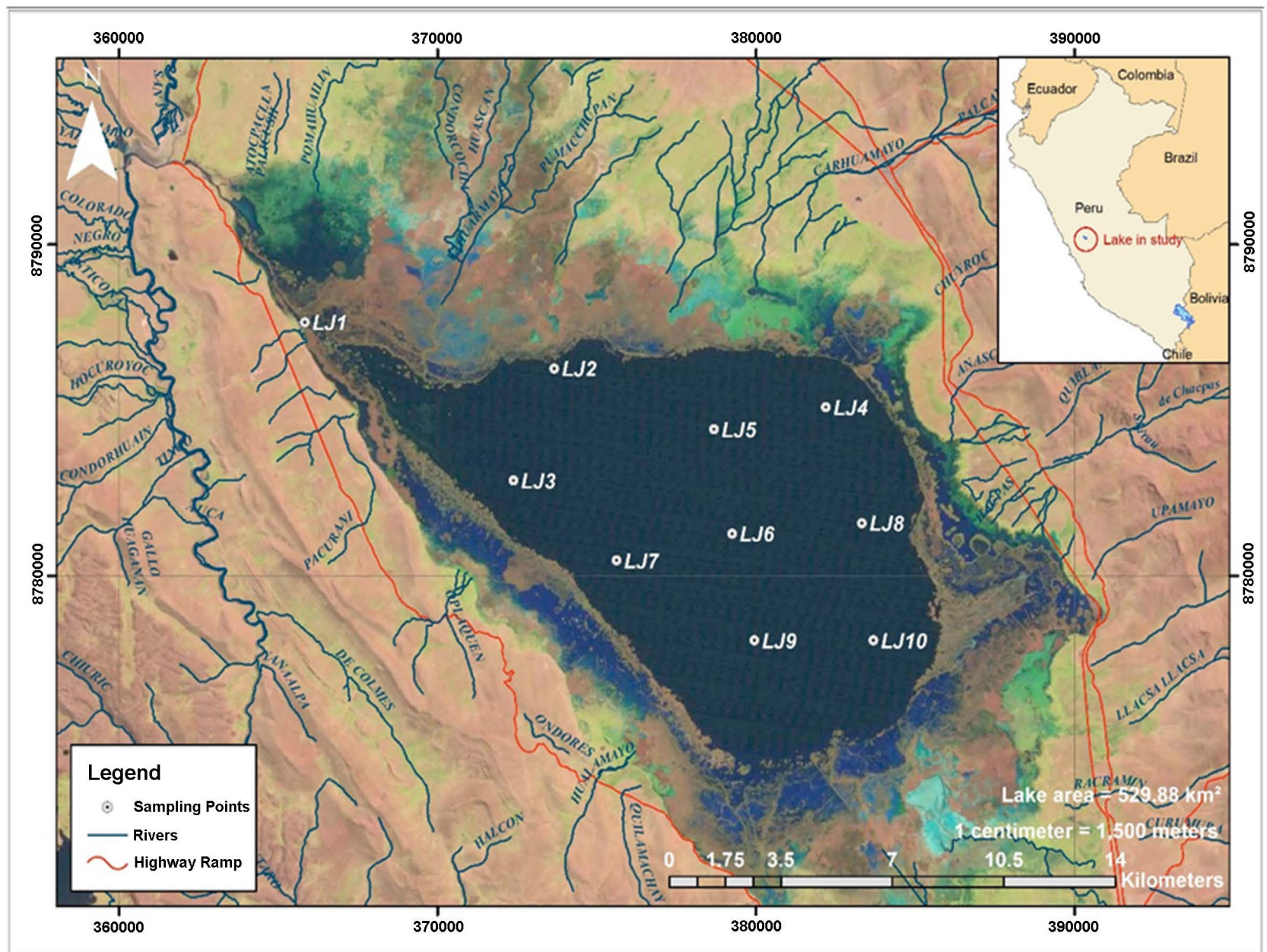

Figure 1. Location of sampling points in Lake Junin National Reserve, Peru.

\subsection{Data Analysis}

\subsubsection{Contamination Factor}

The contamination factor $(C F)$, expressed as the relationship between the concentration of each metal in the sediment and the background value, was applied to quantify the state of contamination by sediment metals as a function of their concentrations in the sample and their background concentration.

The $C F$ values were calculated with the following equation

$$
C F=\frac{C_{m} \text { sample }}{C_{m} \text { background }}
$$

where, " $C_{m}$ sample" is the concentration of specific heavy metals in the sediment sample and " $C_{m}$ background" is the concentration of heavy metal in natural reference sediment [13]. The categories of $C F<1$, are described as low contamination factor; $1-3$, moderate contamination factor; $3-6$, considerable contamination factor, and $\geq 6$ very high contamination factor.

\subsubsection{Pollution Load Index}

The Pollution Load Index ( $P L I)$ was applied to determine metal contamination 
in lake sediments using the procedures of Tomlinson et al. (1980) [14].

$$
P L I=(C F 1 \times C F 2 \times C F 3 \times \cdots \times C F n)^{1 / n}
$$

where $n$ is the number of metals and $C F$ is the contamination factor. $P L I$ is a powerful tool in the assessment of heavy metal contamination. A $P L I$ value of zero indicates perfection, a value of one indicates the presence of only basic levels of contaminants, and values above one would indicate progressive deterioration of the site and the quality of the lake environment.

\subsubsection{Geoaccumulation Index}

The geoaccumulation index $\left(I_{g e o}\right)$ is widely used to determine and calculate sediment contamination by comparing the concentration of a given metal with its geochemical background concentration [15]. The $I_{g e o}$ is an important index for determining sediment quality at each sampling site.

$$
I_{\text {geo }}=\log 2\left(\frac{C_{n}}{1.5 B_{n}}\right)
$$

where $C_{n}$ is the concentration of the metal determined in the sediment, $B_{n}$ is the concentration of the background metal. In Equation (1), the constant value (1.5) is multiplied by the concentration of the background metal in order to correct for natural fluctuations and anthropogenic influence. Müller proposed seven classes of geoaccumulation indices: $I_{\text {geo }} \leq 0$, class 0 (practically unpolluted); $0<$ $I_{\text {geo }}<1$, Class 1 (unpolluted to moderately polluted); $1<I_{\text {geo }}<2$, Class 2 (moderately polluted); $2<I_{\text {geo }}<3$, Class 3 (moderately to heavily polluted); $3<I_{\text {geo }}<$ 4 , Class 4 (heavily polluted); $4<I_{\text {geo }}<5$ Class 5 (heavily to extremely polluted); $I_{g e o}>5$, Class 6 (extremely polluted).

\subsubsection{Statistical Analysis}

The mean descriptive statistics, standard deviation and range of heavy metals and arsenic concentrations measured in Lake Junin sediment were analyzed using the IBM SPSS Statistics 25 software package. Principal component analysis was used to identify important indicators and investigate possible sources of heavy metals in sediment quality. The Spearman correlation analysis was performed to evaluate the relationships between different heavy metals and arsenic.

\section{Results}

\subsection{Distribution of Heavy Metals and Arsenic in Lake Sediment}

Table 1 shows the descriptive statistics of heavy metal and arsenic concentrations in Lake Junin sediment for each sector sampling site. The distribution of the mean values of heavy metals and arsenic was in descending order $\mathrm{Fe}>\mathrm{Cu}>$ $\mathrm{Zn}>\mathrm{As}>\mathrm{Pb}>\mathrm{Cd}>\mathrm{Cr}$ in the three sectors followed this trend. In sector $\mathrm{I}$, the average values of these metals ranged from 209.86 to 319.76 , from 35.78 to 111.76, from 28.65 to 76.18 , from 13.50 to 38.35 , from 13.92 to 24.06 and from 1.07 to $1.92 \mathrm{mg} / \mathrm{Kg}$, respectively. However, most of the mean values of the metals analyzed in the two sampling periods did not exceed the threshold values of the 
Table 1. Descriptive statistics of heavy metals and arsenic concentrations in Lake Junin sediment, according to sector and sampling epoch.

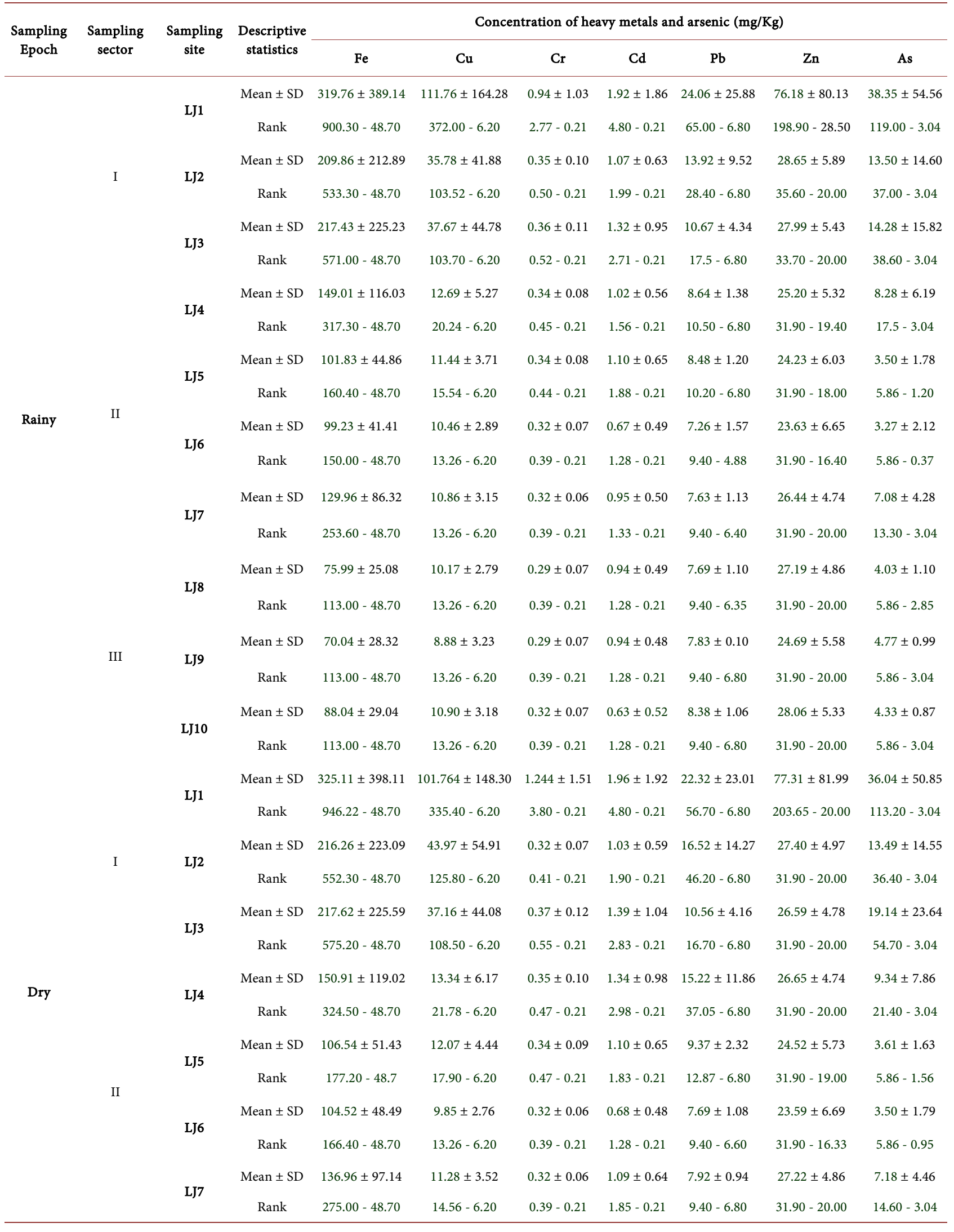




\begin{tabular}{|c|c|c|c|c|c|c|c|c|c|}
\hline \multirow{3}{*}{\multicolumn{2}{|c|}{ LJ8 }} & Mean \pm SD & $76.94 \pm 24.87$ & $10.56 \pm 2.97$ & $0.30 \pm 0.06$ & $0.94 \pm 0.49$ & $7.83 \pm 0.97$ & $26.42 \pm 5.30$ & $4.23 \pm 0.94$ \\
\hline & & & & & & & & & \\
\hline & & Rank & $113.00-48.70$ & $13.26-6.20$ & $0.39-0.21$ & $1.28-0.21$ & $9.40-6.80$ & $31.90-20.00$ & $5.86-3.04$ \\
\hline \multirow{6}{*}{ III } & \multirow{3}{*}{ LJ9 } & Mean \pm SD & $71.66 \pm 27.14$ & $8.87 \pm 3.23$ & $0.30 \pm 0.06$ & $0.97 \pm 0.51$ & $7.95 \pm 0.92$ & $25.44 \pm 5.05$ & $4.77 \pm 0.97$ \\
\hline & & & & & & & & & \\
\hline & & Rank & $113.00-48.70$ & $13.26-6.20$ & $0.27-0.80$ & $1.37-0.21$ & $9.40-6.80$ & $31.90-20.00$ & $5.86-3.04$ \\
\hline & \multirow{3}{*}{ LJ10 } & Mean \pm SD & $88.71 \pm 29.59$ & $10.78 \pm 3.09$ & $0.33 \pm 0.07$ & $0.64 \pm 0.52$ & $8.94 \pm 1.70$ & $28.86 \pm 6.05$ & $4.61 \pm 0.87$ \\
\hline & & & & & & & & & \\
\hline & & Rank & $113.00-48.7$ & $13.26-6.20$ & $0.40-0.21$ & $1.28-0.21$ & $11.10-6.80$ & $35.18-20.00$ & $5.86-3.04$ \\
\hline \multicolumn{10}{|c|}{ International reference limit value $(\mathrm{mg} / \mathrm{Kg})$} \\
\hline \multicolumn{2}{|c|}{ Consensus-based PEC [16] } & Valor umbral & NP & 149.00 & 111.00 & 4.98 & 128.00 & 459.00 & 33.00 \\
\hline \multirow{2}{*}{\multicolumn{2}{|c|}{ Reference Material IAEA-SL-1 [17] }} & Media & $67,400.00$ & 30.00 & 104.00 & 0.26 & 37.70 & 223.00 & 27.60 \\
\hline & & IC $95 \%$ & $6.5700-69100$ & $24-36$ & $95-113$ & $0.21-0.31$ & $303-451$ & $213-233$ & $247-30.5$ \\
\hline \multicolumn{2}{|c|}{$\begin{array}{l}\text { ISQG Canadian interim sediment } \\
\text { quality guideline [18] }\end{array}$} & & NP & 18.70 & 52.30 & 0.70 & 30.20 & 124.00 & 7.24 \\
\hline
\end{tabular}

Probable Effects Concentration (PEC) reported by MacDonald, Ingersoll y Berger (2000) [16], he mean values of the IAEA-SL-1 reference material [17] and the Interim Sediment Quality Guidelines (ISQG) stipulated by the Canadian Council of Ministers of the Environment [18]. However, $\mathrm{Cu}$ and As did not follow this behavior as they exhibited mean values that exceeded the PEC threshold value, the mean value of the IAEA-SL-1 reference material and the ISQG values, at both sampling times. In sector II, Fe presented mean values ranging from $99.23 \mathrm{mg} / \mathrm{Kg}$ to $149.01 \mathrm{mg} / \mathrm{Kg}$, Cu from $10.46 \mathrm{mg} / \mathrm{Kg}$ to $12.69 \mathrm{mg} / \mathrm{Kg}$, Cr from $0.32 \mathrm{mg} / \mathrm{Kg}$ to $0.34 \mathrm{mg} / \mathrm{Kg}$, Cd from $0.67 \mathrm{mg} / \mathrm{Kg}$ to $1.10 \mathrm{mg} / \mathrm{Kg}$, Pb from 7.26 $\mathrm{mg} / \mathrm{Kg}$ to $8.64 \mathrm{mg} / \mathrm{Kg}$, Zn from 23.63 to $26.44 \mathrm{mg} / \mathrm{Kg}$ and As from $3.27 \mathrm{mg} / \mathrm{Kg}$ to $8.28 \mathrm{mg} / \mathrm{Kg}$, in rainy season. The variability of the mean values of heavy metals and arsenic in this sector did not exceed the PEC threshold value; except for cadmium which exceeded the mean value of the reference material $(0.26 \mathrm{mg} / \mathrm{Kg})$ and the ISQG value. In sector III, similar availability behavior of heavy metals and arsenic was observed at the respective sampling sites during the rainy season, but in the low water season the mean values of the metals under study did not exceed the PEC threshold values, the mean values of the IAEA-SL-1 reference material or the ISQG values.

The iron reached its maximum value of $946.22 \mathrm{mg} / \mathrm{Kg}$ in sector I in the dry season, while its lowest value of $48.70 \mathrm{mg} / \mathrm{Kg}$ in the three sampling sectors. Copper showed irregular distribution patterns in the sediment of Lake Junin at both sampling times, ranging from $6.20 \mathrm{mg} / \mathrm{Kg}$ to $372 \mathrm{mg} / \mathrm{Kg}$. The maximum copper value exceeded the PEC threshold value, the mean value of the IAEA-SL-1 reference material and the ISQG value. Chromium had low values ranging from $0.21 \mathrm{mg} / \mathrm{Kg}$ to $3.80 \mathrm{mg} / \mathrm{Kg}$. Cadmium reached mean values that exceeded the values of the reference material $(0.26 \mathrm{mg} / \mathrm{Kg})$ and the ISQG $(0.70 \mathrm{mg} / \mathrm{Kg})$ at all sampling sites; except LJ6 and LJ10 at both sampling times. This value exceeded the mean value of the reference material. Lead reached its maximum value (65.0 $\mathrm{mg} / \mathrm{Kg}$ ) in sector I, exceeding the mean value of the IAEA-SL-1 reference ma- 
terial $(37.7 \mathrm{mg} / \mathrm{Kg})$ and the ISQG $(30.20 \mathrm{mg} / \mathrm{Kg})$; however, it did not exceed the PEC threshold value. Zinc at both sampling times presented contents that did not exceed the PEC threshold value, the ISQG value or the mean value of reference material IAEA-SL-1. Meanwhile, arsenic exhibited values that exceeded these reference values in sector I at both sampling times. The values for heavy metals and the lowest arsenic were recorded in sector III, at sites LJ8, LJ9 and LJ10 located in the southern part of Lake Junin.

\section{Analysis of Main Components}

The analysis of major components (PCA) of the concentration of heavy metals and arsenic and sampling sites is presented in Figure 2. The percentage of total variation of the observations of the first major axis was 90.15\%; this indicates that the distribution of the data is due to particular characteristics and that its interpretation is very close to the actual observation. The perceptual map shows that there is no marked difference between sampling times. However, site LJ1 presents significant differences with respect to the other sites. The PCA also reveals that there are significant loads of heavy metals and arsenic that significantly influence sediment quality.

The results of the Spearman correlation analysis show positive and significant correlations ( $\mathrm{p}<0.05)$ between $\mathrm{Fe} / \mathrm{Cu}(\mathrm{r}=0.9248), \mathrm{Fe} / \mathrm{Cr}(\mathrm{r}=0.8226), \mathrm{Fe} / \mathrm{Cd}(\mathrm{r}$ $=0.7895), \mathrm{Fe} / \mathrm{Pb}(\mathrm{r}=0.7492), \mathrm{Fe} / \mathrm{Zn}(\mathrm{r}=0.4797), \mathrm{Fe} / \mathrm{As}(\mathrm{r}=0.7789), \mathrm{Cu} / \mathrm{Cr}(\mathrm{r}=$ $0.8406), \mathrm{Cu} / \mathrm{Cd}(\mathrm{r}=0.7880), \mathrm{Cu} / \mathrm{Pb}(\mathrm{r}=0.8733), \mathrm{Cu} / \mathrm{Zn}(\mathrm{r}=0.5835), \mathrm{Cu} / \mathrm{Cr}(\mathrm{r}=$ 0.7684), $\mathrm{Cr} / \mathrm{Cd}(\mathrm{r}=0.7203), \mathrm{Cu} / \mathrm{Pb}(\mathrm{r}=0.8011), \mathrm{Cr} / \mathrm{Zn}(\mathrm{r}=0.4376), \mathrm{Cr} / \mathrm{As}(\mathrm{r}=$ $0.5985), \mathrm{Cd} / \mathrm{Pb}(\mathrm{r}=0.7341), \mathrm{Cd} / \mathrm{As}(\mathrm{r}=0.6962), \mathrm{Pb} / \mathrm{Zn}(\mathrm{r}=0.6386), \mathrm{Pb} / \mathrm{As}(\mathrm{r}=$ $0.7574)$ and $\mathrm{Zn} / \mathrm{As}(\mathrm{r}=0.7023)$, except for $\mathrm{Cd} / \mathrm{Zn}$. The correlations found suggest the common origin or sink of heavy metals and arsenic in the lake sediment.

\subsection{Accumulation of Heavy Metals and Arsenic in Lake Sediment}

Table 2 shows the values of the pollution factor $(C F)$ and pollution load index $(P L I)$ of heavy metals and arsenic obtained from the average values of their sediment concentrations in Lake Junin. In all three sectors, the $C F$ values obtained for most metals qualified as a low contamination factor $(C F<1)$ both in the rainy and low water season. In sector I, $\mathrm{Cu} C F$ values ranged from 1.1927 to 3.7253 in the rainy season and from 1.2387 to 3.3921 in the dry season, showing moderate contamination factors at LJ2 and LJ3 sites (1 - 3: moderate $C F$ ) and considerable contamination factors at LJ1 (3 - 6: considerable $C F)$. Arsenic $C F$ values qualified as moderate contamination factors. However, cadmium $C F$ values ranked as moderate contamination factors at all sampling sites except LJ1 where it ranked as a significant contamination factor at both sampling times. The PLI in sectors I, II and III of Lake Junin ranged from 0.0721 to 0.3260 ; indicating that there is no appreciable contamination by these metals.

Table 3 shows the values of the geoaccumulation index $\left(I_{g e o}\right)$ of heavy metals and arsenic obtained from the average values of their sediment concentrations in 


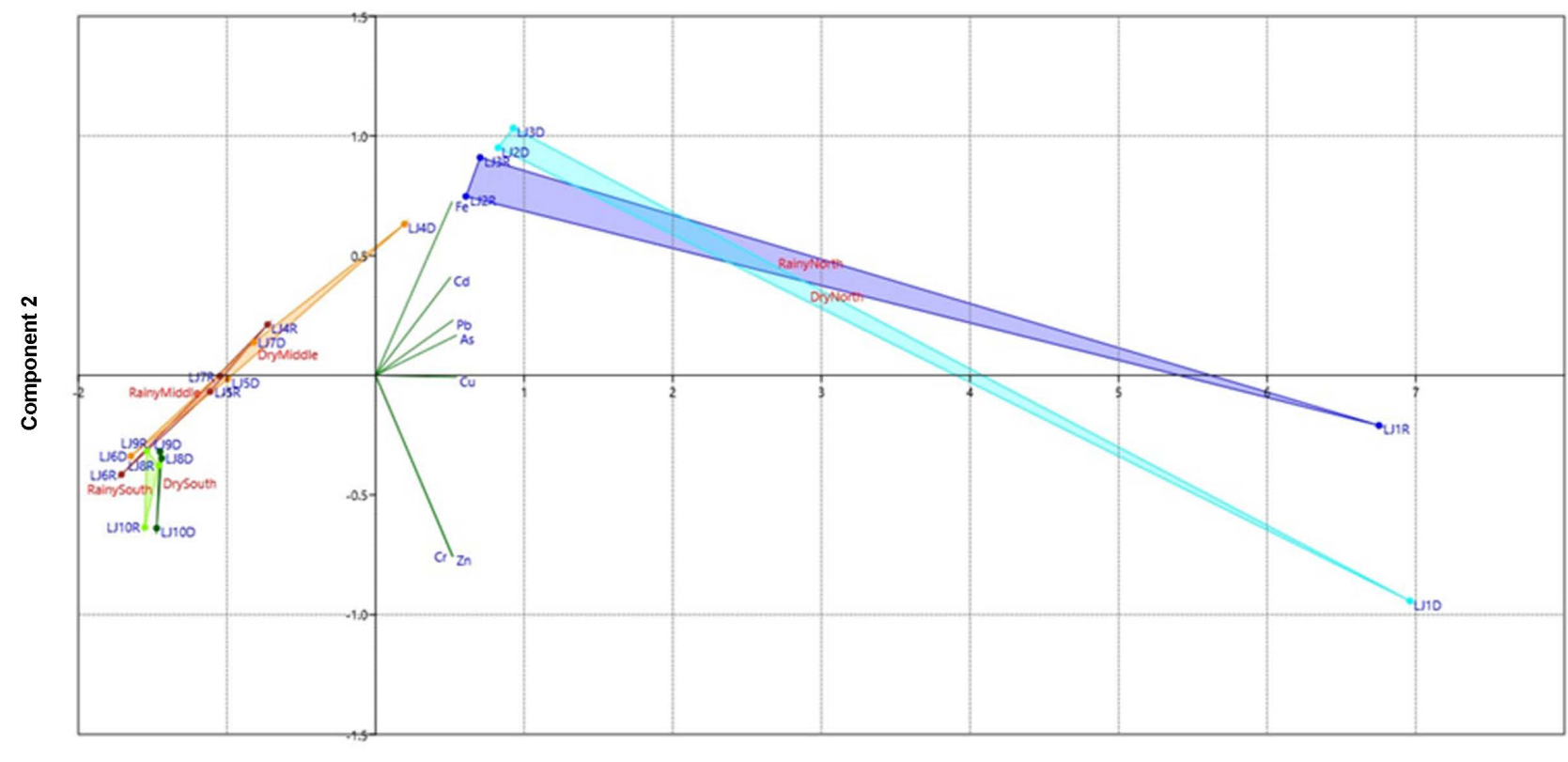

Component 1

Figure 2. Analysis of the main components of the sampling sites of Lake Junín, from the concentrations of heavy metals and arsenic in sediment.

Table 2. Contamination factor and pollution load index of heavy metals and arsenic in Lake Junin sediment, according to sector and epoch of sampling.

\begin{tabular}{|c|c|c|c|c|c|c|c|c|c|c|}
\hline \multirow{2}{*}{$\begin{array}{l}\text { Sampling } \\
\text { Epoch }\end{array}$} & \multirow{2}{*}{$\begin{array}{l}\text { Sampling } \\
\text { sector }\end{array}$} & \multirow{2}{*}{$\begin{array}{l}\text { Sampling } \\
\text { site }\end{array}$} & \multicolumn{7}{|c|}{ Contamination factor $(C F)$} & \multirow[t]{2}{*}{$P L I$} \\
\hline & & & $\mathrm{Fe}$ & $\mathrm{Cu}$ & $\mathrm{Cr}$ & $\mathrm{Cd}$ & $\mathrm{Pb}$ & $\mathrm{Zn}$ & As & \\
\hline \multirow{10}{*}{ Rainy } & \multirow{3}{*}{ I } & LJ1 & 0.0047 & 3.7253 & 0.0090 & 7.3846 & 0.6382 & 0.3416 & 1.3967 & 0.3214 \\
\hline & & LJ2 & 0.0031 & 1.1927 & 0.0034 & 4.1154 & 0.3692 & 0.1285 & 0.4891 & 0.1426 \\
\hline & & LJ3 & 0.0032 & 1.2557 & 0.0034 & 5.0769 & 0.2830 & 0.1255 & 0.5174 & 0.1439 \\
\hline & \multirow{4}{*}{ II } & LJ4 & 0.0022 & 0.4230 & 0.0033 & 3.9231 & 0.2292 & 0.1130 & 0.3000 & 0.0991 \\
\hline & & LJ5 & 0.0015 & 0.3813 & 0.0033 & 4.2308 & 0.2249 & 0.1087 & 0.1268 & 0.0819 \\
\hline & & LJ6 & 0.0015 & 0.3487 & 0.0031 & 2.5769 & 0.1926 & 0.1060 & 0.1185 & 0.0721 \\
\hline & & LJ7 & 0.0019 & 0.3620 & 0.0031 & 3.6538 & 0.2024 & 0.1186 & 0.2565 & 0.0900 \\
\hline & \multirow{3}{*}{ III } & LJ8 & 0.0011 & 0.3390 & 0.0028 & 3.6154 & 0.2040 & 0.1219 & 0.1460 & 0.0753 \\
\hline & & LJ9 & 0.0010 & 0.2960 & 0.0028 & 3.6154 & 0.2077 & 0.1107 & 0.1728 & 0.0738 \\
\hline & & LJ10 & 0.0013 & 0.3633 & 0.0033 & 2.4231 & 0.223 & 0.1258 & 0.1569 & 0.0774 \\
\hline \multirow{10}{*}{ Dry } & \multirow{3}{*}{ I } & LJ1 & 0.0048 & 3.3921 & 0.0119 & 7.5385 & 0.5920 & 0.3467 & 1.3058 & 0.3260 \\
\hline & & LJ2 & 0.0032 & 1.4657 & 0.0031 & 3.9615 & 0.4382 & 0.1229 & 0.4888 & 0.1475 \\
\hline & & LJ3 & 0.0032 & 1.2387 & 0.0036 & 5.3462 & 0.2801 & 0.1192 & 0.6935 & 0.1507 \\
\hline & \multirow{4}{*}{ II } & LJ4 & 0.0022 & 0.4447 & 0.0034 & 5.1538 & 0.4037 & 0.1195 & 0.3384 & 0.1158 \\
\hline & & LJ5 & 0.0016 & 0.4023 & 0.0033 & 4.2308 & 0.2485 & 0.1099 & 0.1308 & 0.0850 \\
\hline & & LJ6 & 0.0016 & 0.3283 & 0.0031 & 2.6154 & 0.2040 & 0.1058 & 0.1268 & 0.0736 \\
\hline & & LJ7 & 0.0020 & 0.3760 & 0.0031 & 4.1923 & 0.2101 & 0.1221 & 0.2601 & 0.0941 \\
\hline & \multirow{3}{*}{ III } & LJ8 & 0.0011 & 0.3520 & 0.0029 & 3.6154 & 0.2077 & 0.1185 & 0.1533 & 0.0765 \\
\hline & & LJ9 & 0.0011 & 0.2957 & 0.0029 & 3.7308 & 0.2109 & 0.1141 & 0.1728 & 0.0760 \\
\hline & & LJ10 & 0.0013 & 0.3593 & 0.0032 & 2.4615 & 0.2371 & 0.1294 & 0.1670 & 0.0788 \\
\hline
\end{tabular}


Table 3. Index of geoaccumulation of heavy metals and arsenic in Lake Junin sediment, by sector and epoch of sampling.

\begin{tabular}{|c|c|c|c|c|c|c|c|c|c|}
\hline \multirow{2}{*}{$\begin{array}{l}\text { Sampling } \\
\text { epoch }\end{array}$} & \multirow{2}{*}{$\begin{array}{l}\text { Sampling } \\
\text { sector }\end{array}$} & \multirow{2}{*}{$\begin{array}{l}\text { Sampling } \\
\text { site }\end{array}$} & \multicolumn{7}{|c|}{ Index of geoaccumulation $\left(I_{g e o}\right)$} \\
\hline & & & $\mathrm{Fe}$ & $\mathrm{Cu}$ & $\mathrm{Cr}$ & $\mathrm{Cd}$ & $\mathrm{Pb}$ & $\mathrm{Zn}$ & As \\
\hline \multirow{10}{*}{ Rainy } & \multirow{3}{*}{ I } & LJ1 & 0.0009 & 0.7476 & 0.0018 & 1.4820 & 0.1281 & 0.0686 & 0.2789 \\
\hline & & LJ2 & 0.0006 & 0.2324 & 0.0007 & 0.8259 & 0.0741 & 0.0258 & 0.0982 \\
\hline & & LJ3 & 0.0006 & 0.2520 & 0.0007 & 1.0189 & 0.0568 & 0.0252 & 0.1038 \\
\hline & \multirow{4}{*}{ II } & LJ4 & 0.0004 & 0.0849 & 0.0007 & 0.7873 & 0.0460 & 0.0227 & 0.0602 \\
\hline & & LJ5 & 0.0003 & 0.0765 & 0.0007 & 0.8491 & 0.0451 & 0.0218 & 0.0254 \\
\hline & & LJ6 & 0.0003 & 0.0700 & 0.0006 & 0.5172 & 0.0365 & 0.0213 & 0.0238 \\
\hline & & LJ7 & 0.0004 & 0.0726 & 0.0006 & 0.7333 & 0.0406 & 0.0238 & 0.0515 \\
\hline & \multirow{3}{*}{ III } & LJ8 & 0.0002 & 0.0680 & 0.0006 & 0.7256 & 0.0409 & 0.0245 & 0.0293 \\
\hline & & LJ9 & 0.0002 & 0.0594 & 0.0006 & 0.7256 & 0.0416 & 0.0222 & 0.0347 \\
\hline & & LJ10 & 0.0003 & 0.0729 & 0.0006 & 0.4863 & 0.0446 & 0.0253 & 0.0315 \\
\hline \multirow{10}{*}{ Dry } & \multirow{3}{*}{ I } & LJ1 & 0.0010 & 0.6807 & 0.0024 & 1.5129 & 0.1188 & 0.0696 & 0.2621 \\
\hline & & LJ2 & 0.0006 & 0.2941 & 0.0006 & 0.7950 & 0.0879 & 0.0247 & 0.0981 \\
\hline & & LJ3 & 0.0006 & 0.2486 & 0.0007 & 1.0729 & 0.0562 & 0.0239 & 0.1392 \\
\hline & \multirow{4}{*}{ II } & LJ4 & 0.0004 & 0.0892 & 0.0006 & 1.0343 & 0.0810 & 0.0240 & 0.0679 \\
\hline & & LJ5 & 0.0003 & 0.0807 & 0.0007 & 0.8491 & 0.0499 & 0.0221 & 0.0262 \\
\hline & & LJ6 & 0.0003 & 0.0658 & 0.0006 & 0.5249 & 0.0409 & 0.0212 & 0.0254 \\
\hline & & LJ7 & 0.0004 & 0.0754 & 0.0006 & 0.8413 & 0.0422 & 0.0245 & 0.0522 \\
\hline & \multirow{3}{*}{ III } & LJ8 & 0.0002 & 0.0706 & 0.0006 & 0.7256 & 0.0417 & 0.0238 & 0.0308 \\
\hline & & LJ9 & 0.0002 & 0.0593 & 0.0006 & 0.7487 & 0.0423 & 0.0229 & 0.0347 \\
\hline & & LJ10 & 0.0003 & 0.0721 & 0.0007 & 0.4940 & 0.0476 & 0.0260 & 0.0335 \\
\hline
\end{tabular}

Lake Junin. The values of the $I_{\text {geo }}$ obtained were $<1$, in $80 \%$ of the sampling sites, corresponding to class 1 . The $I_{g e o}$ obtained indicates that the sampling sites are not contaminated by the heavy metals under study or are moderately contaminated. The $I_{g e o}$ of Fe and Cr follows a tendency to be $I_{g e o}=0$, indicating that the sampling sites are not contaminated with these metals. The $I_{\text {geo }}$ values of $\mathrm{Cu}, \mathrm{Pb}$, Zn show an upward trend, $0>I_{\text {geo }}<1$, indicating that the sites show signs of contamination, while the $I_{\text {geo }}$ values of Cd in $20 \%$ of the sampling sites were $1<$ $I_{\text {geo }}<2$, showing that they are moderately contaminated, at both sampling times.

\section{Discussion}

\subsection{Spatial and Temporal Distribution of Heavy Metals and Arsenic in Lake Sediment}

The mean concentration values of heavy metals and arsenic obtained in the sediment of Lake Junin were compared with the PEC threshold values [16], the mean values of reference material IAEA-SL-1 [17] and the provisional sediment quality guidelines (ISQG) revealing that they did not exceed these values. The 
results also indicate a narrow dispersion of these metals and arsenic at most sampling sites. The results obtained show lower concentrations compared to the results of the 2014 participatory monitoring of water and sediment quality of Lake Junin by the National Water Authority [11]. However, the mean values of the concentrations of $\mathrm{Cu}$ and As in sediment at site LCh1 far exceeded the reference values. These results could be related to the discharge of domestic and industrial wastewater from the populations surrounding the lake, through the tributary rivers Hualamayo and Carhuamayo, which presented high concentrations of $\mathrm{As}, \mathrm{Pb}$ and $\mathrm{Zn}$ in the participatory monitoring of 2014. In addition, they receive metallic contributions from other tributary rivers coming from areas with high mining activity; as well as from runoff from adjacent agricultural areas that are dedicated to the intensive cultivation of Lepidium meyenii Walpers, which could be responsible for the release of $\mathrm{Cu}, \mathrm{Cd}, \mathrm{Pb}$ and $\mathrm{Zn}$; since these are present in fertilizers and pesticides [19]. The increase of these metals could affect the geochemistry of the sediment and cause negative impacts to the biota.

Iron is the fourth most abundant metal in the earth's crust, present in natural waters. In the aquatic environment, the chemical behavior of iron is determined by $\mathrm{pH}$, oxide-reduction reactions and inorganic and organic complexes [20]. The concentrations of this metal found in the study did not exceed the international reference values, which indicates that there is no contamination of the sediment by iron.

Copper, as an essential trace element, is required by biological systems for the activation of some enzymes during photosynthesis [21]. However, in aquatic environments copper is toxic to a variety of organisms, even at very low concentrations [20]. Mining activities in areas adjacent to the lake and the discharge of domestic and industrial wastewater would be the main sources of copper loading in the aquatic environment. Despite results with copper concentrations not exceeding the IAEA-SL-1 and ISQG reference material values in sectors II and III [17] [18], the sediments in sector I continue to show concentrations that reveal contamination. This can be attributed to the resuspension and transport of old sediments by the tributary rivers to the lake.

Chromium is an essential micronutrient for animals and plants. It is considered an element of biological importance and relative contamination [7]. Generally, the natural chromium content in water is very low, except in regions where it is used extensively in industrial processes; this generates large amounts of wastewater with high concentrations of chromium in water bodies. Chromium enters the aquatic environment through natural (volcanic eruptions, geological weathering of rocks, soils and sediments) and anthropogenic (burning of fossil fuels, production of chromates, manufacture of plastics, electroplating of metals and leather industries) sources. The results obtained reveal that there is no contamination of the sediments by this heavy metal.

Cadmium occurs naturally in soil and rocks. It is widely used in galvanic industries, welding, batteries, televisions, ceramics, photography, insecticides, electronics, metal finishing industries and metallurgical activities [22]. The 
findings of this metal in Lake Junin exceed the mean value of the IAEA-SL-1 reference material and those of the ISQG of Canada in the three sampling sectors (northern, central and southern part of the lake). Although the concentrations of this metal are lower than those reported by the National Water Authority [11], they are still of concern. These results can be attributed to point and diffuse sources of pollution such as cadmium-containing pigments, cadmium-containing phosphate fertilizers, waste water, detergents, nickel-cadmium rechargeable batteries and other industrial activities.

Lead is a heavy metal found as metallic lead, inorganic and organometallic compounds. Lead is found in nature in the forms tetravalent $\left(\mathrm{Pb}^{+4}\right)$ and divalent $\left(\mathrm{Pb}^{+2}\right)$, where $\mathrm{Pb}^{+2}$ is predominant and slightly soluble in water [23]. Lead is extremely toxic to most life forms, especially aquatic organisms [24]. The high content of lead found in sector I becomes a concern for the administrators of the water resource and the Junin National Reserve due to the toxicity it represents for human beings and the organisms whose habitat is the lake.

$\mathrm{Zn}$ is an essential element for life; it activates enzymes. It is found in food and drinking water in the form of salts or organic complexes [25]. The main sources of $\mathrm{Zn}$ contamination of the aquatic environment are zinc-containing fertilizers, sewage sludge and mining. Urban runoff, mine drainage, and municipal wastewater are the most concentrated sources of zinc in water [26]. The $\mathrm{Zn}$ does not accumulate in the body; its action in the aquatic fauna depends on the hardness of the water, oxygen and temperature. The salts of alkaline earth elements reduce the toxicity of $\mathrm{Zn}$, while increasing the temperature, while the decrease in the concentration of dissolved oxygen increases the toxicity of $\mathrm{Zn}$ [27]. The registered contents of this metal in Lake Junín did not exceed the international reference values.

As is found in the earth's crust, in minerals in the form of amorphous and crystalline powder, in certain areas the concentration of arsenic may be higher than normal and creates serious health hazards for humans and animals. It enters the environment through natural rock weathering, mining and smelting processes, pesticide use, and coal combustion. The results showed arsenic contents that exceeded the PEC, IAEA-SL-1 reference material and ISQG values in the lake sector I. The results showed arsenic contents that exceeded the PEC, IAEA-SL-1 reference material and ISQG values in the lake sector I. The arsenic and heavy metal contents recorded in this study are lower than those reported by the National Water Authority in 2014; this would reveal the results of the actions of the Chinchaycocha 2017-2021 Sustainable Environmental Management Plan, assumed by the Peruvian government in the Junin National Reserve.

\subsection{Accumulation of Heavy Metals and Arsenic in Lake Sediment}

The sources of heavy metal contamination of sediments are natural and anthropogenic. Therefore, due to their biological toxicity, the geochemical properties and transferability of heavy metals could be modified [28]. The $C F$ values of the heavy metals studied and the As revealed that Lake Junin has low, moderate and considerable pollution. The high $C F$ values are due to the strong pressure ex- 
erted by the waters of the Upamayo dam that receives the waters of the San Juan River; which transports high contents of these chemical elements, products of the mining exploitation that takes place in the area [29]. Other important sources of pollution are the Carhuamayo, Hualamayo, Chacachimpa and Pomahuilin rivers, tributaries of the lake [11]. The persistence of sediment contamination could cause latent effects, as metals can move through the food chain and negatively impact aquatic biota [30].

Excessive exposure or ingestion of contaminated aquatic biota can be toxic to birds, fish and other vertebrates. $P L I$ values of evaluated Lake Junin sediments do not reveal appreciable contamination with these metals. However, PLI can provide some understanding to the public about the quality of some component of their environment, as it requires the spatial-temporal trend. In addition, it provides valuable information to water resource managers on the level of contamination that a body of water can present.

The $I_{\text {geo }}$ obtained reveals that the sampling sites of Lake LJ1 and LJ3 are moderately contaminated by $\mathrm{Cd}$. This can be attributed to anthropogenic sources through the contribution of tributary rivers near these sites. The contamination by $\mathrm{Cd}$ constitutes a risk for the aquatic environment; since it affects the behavior of predation, feeding, social, growth and reproductive function. In addition, the persistence of $\mathrm{Cd}$ in sediments could cause latent effects, as this metal can move through the food chain and impact aquatic life. Continuous monitoring of the lake is suggested in order to contribute to the conservation status of the lake, the diversity of birds that it shelters, since it would benefit the Junin National Reserve. In addition, in Peru it is necessary to establish a regulation on the control of sediment contamination, since when contaminated sediments are altered, heavy metals and metalloids attached to sediments can be returned to the water column, affecting water quality and the structure of ecosystems.

\section{Conclusion}

The concentrations of heavy metals and arsenic in Lake Junín sediment were determined in order to evaluate their distribution and accumulation. Most of the mean values of the metal concentrations analyzed in the two sampling periods did not exceed the PEC, IAEA-SL-1 and ISQG reference material values. $\mathrm{Cu}$ and As exhibited mean values that exceeded the reference limit values at both sampling times. All heavy metals studied $\mathrm{Fe}, \mathrm{Cu}, \mathrm{Cr}, \mathrm{Cd}, \mathrm{Pb} \mathrm{Zn}$; as well as As in the sediments of the 10 Junin Lake sampling sites revealed a low contamination factor $(C F<1)$ for most metals, while the values of $C F$ were qualified as moderate pollution factor and for $\mathrm{Cd}$ as considerable pollution factor. The PLI in sectors I, II and III of Lake Junin revealed that there is no appreciable contamination with these metals. The $I_{g e o}$ obtained reveals that the sampling sites of Lake LJ1 and LJ3 are moderately contaminated by $\mathrm{Cd}$.

\section{Recommendations}

It is recommended that in the near future, sediment quality standards be imple- 
mented to regulate heavy metal contributing discharges. As well as, systematic research to monitor metal loading and change in sediment quality.

\section{Words of Gratitude}

The authors express their gratitude to the General Research Institute of the Universidad Nacional del Centro del Peru for the financing of the study, to the Water Research Laboratory for allowing us to make use of the equipment and materials for this study

\section{Conflicts of Interest}

The authors declare that they have no conflict of interest.

\section{References}

[1] Manoj, K., Padhy, P.K., Hirst, H., Jüttner, I., Ormerod, S.J., Köse, E., Prat, N., et al. (2017) Distribution, Contamination and Accumulation of Heavy Metals in Water, Sediments, and Freshwater Shellfish from Liuyang River, Southern China. Science of the Total Environment, 40, 90-97.

[2] Chelarescu, E.D., Radulescu, C., Stihi, C., Bretcan, P., Tanislav, D., Dulama, I.D., Morarescu, C., et al. (2017) Analysis of Elements in Lake Sediment Samples by PIXE Spectrometry. Nuclear Instruments and Methods in Physics Research, Section B: Beam Interactions with Materials and Atoms, 406, 58-60. https://doi.org/10.1016/j.nimb.2017.02.005

[3] Barut, I.F., Ergin, M., Meriç, E., Avşar, N., Nazik, A. and Suner, F. (2017) Contribution of Natural and Anthropogenic Effects in the Iznik Lake Bottom Sediment: Geochemical and Microfauna Assemblages Evidence. Quaternary International, 486, 129-142.

[4] Li, H., Lin, L., Ye, S., Li, H. and Fan, J. (2017) Assessment of Nutrient and Heavy Metal Contamination in the Seawater and Sediment of Yalujiang Estuary. Marine Pollution Bulletin, 117, 499-506. https://doi.org/10.1016/j.marpolbul.2017.01.069

[5] Redwan, M. and Elhaddad, E. (2017) Heavy Metals Seasonal Variability and Distribution in Lake Qaroun Sediments, El-Fayoum, Egypt. Journal of African Earth Sciences, 134, 48-55. https://doi.org/10.1016/j.jafrearsci.2017.06.005

[6] Zhao, D., Wan, S., Yu, Z. and Huang, J. (2015) Distribution, Enrichment and Sources of Heavy Metals in Surface Sediments of Hainan Island Rivers, China. Environmental Earth Sciences, 74, 5097-5110. https://doi.org/10.1007/s12665-015-4522-4

[7] Khan, M.Z.H., Hasan, M.R., Khan, M., Aktar, S. and Fatema, K. (2017) Distribution of Heavy Metals in Surface Sediments of the Bay of Bengal Coast. Journal of Toxicology, 2017, 1-7. https://doi.org/10.1155/2017/9235764

[8] Sartori, L., Canobbio, S., Cabrini, R., Fornaroli, R. and Mezzanotte, V. (2015) Macroinvertebrate Assemblages and Biodiversity Levels: Ecological Role of Constructed Wetlands and Artificial Ponds in a Natural Park. Journal of Limnology, 74, 335-345.

[9] Medrano, R. and Chamorro, A. (2010) Plan de manejo con fines de conservación de las especies de aves amenazadas del lago Chinchaycocha. Vol. 85, Asociación de Ecosistemas Andinos.

[10] SERNANP (2017) Humedales en áreas naturales protegidas, fuentes de vida y 
desarrollo. Vol. 73, Ministerio del Ambiente.

[11] National Water Authority (2014) Assessment of the State of Water Quality in the Sub-Basin of the San Juan River Tributary of the Mantaro River Basin in the Province of Pasco, Pasco.

[12] USEPA (2007) Method 3051A: Microwave Assisted Digestion of Sediments, Sludges, Soils and Oils. Test Methods. Zhurnal Eksperimental noi i Teoreticheskoi Fiziki.

[13] El-amier, Y.A., Elnaggar, A.A. and El-alfy, M.A. (2017) Egyptian Journal of Basic and Applied Sciences Evaluation and Mapping Spatial Distribution of Bottom Sediment Heavy Metal Contamination in Burullus Lake, Egypt. Egyptian Journal of Basic and Applied Sciences, 4, 55-66. https://doi.org/10.1016/j.ejbas.2016.09.005

[14] Tomlinson, D.L., Wilson, J.G., Harris, C.R. and Jeffrey, D.W. (1980) Problems in the Assessment of Heavy-Metal Levels in Estuaries and the Formation of a Pollution Index. Helgolander Meeresunters, 33, 566-575. https://doi.org/10.1007/BF02414780

[15] Müller, G. (1979) Heavy Metals in the Sediment of the Rhine-Changes Seitt. Umschau in Wissenschaft und Technik, 79, 778-783.

[16] MacDonald, D.D., Ingersoll, C.G. and Berger, T.A. (2000) Development and Evaluation of Consensus-Based Sediment Quality Guidelines for Freshwater Ecosystems. Archives of Environmental Contamination and Toxicology, 39, 20-31. https://doi.org/10.1007/s002440010075

[17] International Atomic Energy Agency (1999) Reference Sheet for IAEA-SL-1 Trace and Miner Elements in Lake Sediments. 1-4.

[18] Sediment, C., Guidelines, Q. and Life, A. (2001) Canadian Sediment Quality Guidelines for the Protection of Aquatic Life-Polychlorinated Dibenzo-p-Dioxins and Polychlorinated Dibenzofurans (PCDD/Fs).

[19] Ragab, S., Sikaily, A.El., Nemr, A.El. and Sea, R. (2016) Concentrations and Sources of Pesticides and PCBs in Surficial Sediments of the Red Sea Coast, Egypt. The Egyptian Journal of Aquatic Research, 42, 365-374. https://doi.org/10.1016/j.ejar.2016.09.007

[20] Mohamaden, M.I.I., Khalil, M.K., Draz, S.E.O. and Hamoda, A.Z.M. (2017) Ecological Risk Assessment and Spatial Distribution of Some Heavy Metals in Surface Sediments of New Valley, Western Desert, Egypt. Egyptian Journal of Aquatic Research, 43, 31-43. https://doi.org/10.1016/j.ejar.2016.12.001

[21] Wang, Z., Yao, L., Liu, G. and Liu, W. (2014) Heavy Metals in Water, Sediments and Submerged Macrophytes in Ponds around the Dianchi Lake, China. Ecotoxicology and Environmental Safety, 107, 200-206.

https://doi.org/10.1016/j.ecoenv.2014.06.002

[22] Bindu, K.R., Deepulal, P.M., Gireeshkumar, T.R. and Chandramohanakumar, N. (2015) Evaluation of Heavy Metal Enrichment in Cochin Estuary and Its Adjacent Coast: Multivariate Statistical Approach. Environmental Monitoring and Assessment, 187, 519. https://doi.org/10.1007/s10661-015-4749-2

[23] Iqbal, J., Shah, M.H. and Shaheen, N. (2015) Distribution, Source Identification and Risk Assessment of Selected Metals in Sediments from Freshwater Lake. International Journal of Sediment Research, 30, 241-249.

https://doi.org/10.1016/j.ijsrc.2012.12.001

[24] Custodio, M., Peñaloza, R., Chanamé, F., Yaranga, R. and Pantoja, R. (2018) Assessment of the Aquatic Environment Quality of High Andean Lagoons Using Multivariate Statistical Methods in Two Contrasting Climatic Periods. Egyptian Journal of Aquatic Research, 19, 24-33. 
[25] WHO (2011) WHO Guidelines for Drinking-Water Quality. 4th Edition.

[26] Bytyçi, P., Fetoshi, O., Durmishi, B.H., Etemi, F.Z., Çadraku, H., Ismaili, M. and Abazi, A.S. (2018) Status Assessment of Heavy Metals in Water of the Lepenci River Basin, Kosova. Journal of Ecological Engineering, 19, 19-32. https://doi.org/10.12911/22998993/91273

[27] Zhang, Y., Han, Y., Yang, J., Zhu, L. and Zhong, W. (2017) Toxicities and Risk Assessment of Heavy Metals in Sediments of Taihu Lake, China, Based on Sediment Quality Guidelines. Journal of Environmental Sciences (China), 62, 31-38. https://doi.org/10.1016/j.jes.2017.08.002

[28] Libralato, G., Minetto, D., Lofrano, G., Guida, M., Carotenuto, M., Aliberti, F., Notarnicola, M., et al. (2018) Toxicity Assessment within the Application of in Situ Contaminated Sediment Remediation Technologies: A Review. Science of the Total Environment, 621, 85-94. https://doi.org/10.1016/j.scitotenv.2017.11.229

[29] Hu, Y., Dong, Z. and Liu, G. (2017) Distribution and Potential Ecological Risk of Heavy Metals Accumulated in Subsidence Lakes Formed in the Huainan Coalfield, China. Environmental Forensics, 18, 251-257. https://doi.org/10.1080/15275922.2017.1368040

[30] National Water Authority (2014) Participatory Monitoring of Water Quality in Lake Chinchaycocha (Flood Season) Junin-Pasco. 